\title{
Dynamics of oxygen production / consumption in Dunaliella salina, Thalassiosira weissflogii and Heterocapsa triquetra circulating within a simulated upper mixed layer*
}

\author{
Elena S. Barbieri ${ }^{1}$, Virginia E. Villafañe ${ }^{1}$ \& E. Walter Helbling ${ }^{1}$ \\ ${ }^{1}$ Estación de Fotobiología Playa Unión \& Consejo Nacional de Investigaciones Científicas y Técnicas \\ (CONICET) \\ Casilla de Correos $N^{\circ}$ 15.9103, Rawson, Chubut, Argentina
}

\begin{abstract}
Oxygen production / consumption dynamics in three phytoplankton species (20-25 $\mu \mathrm{m}$ in effective diameter), Dunaliella salina (Chlorophyceae), Thalassiosira weissflogii (Bacillariophyceae) and Heterocapsa triquetra (Dinophyceae), was experimentally determined when cells circulated within a simulated upper mixed layer (UML). Samples were exposed to three radiation treatments receiving: a) full solar radiation (PAB, 280-700 nm), b) PAR+UV-A $(\mathrm{PA}, 320-700 \mathrm{~nm}$ ), and c) only PAR (P, 400-700 nm). Two pathways were simulated (as if the cells started to circulate from the surface or from the bottom of the UML): 1) downward circulation (i.e., from $100 \%$ to $9 \%$ irradiance and back to $100 \%$ ), and 2) upward circulation (i.e., from $9 \%$ to $100 \%$ irradiance and back to $9 \%$ ). There were no significant differences among radiation treatments $(\mathrm{p}<0.05)$ and photosynthetic inhibition was only due to PAR. We found important inter-specific differences in $\mathrm{O}_{2}$ rates when cells circulated within the simulated UML, $D$. salina was affected by both high and low irradiances whereas $T$. weissflogii was only inhibited by high irradiances. On the other hand, H. triquetra showed the least variability and it benefited by fluctuating radiation regimes. We also determined differences in the depth integrated $\mathrm{O}_{2}$ production when species performed a complete rotation within the simulated UML, with the highest values in $H$. triquetra and the lowest in $D$. salina. Our findings suggest that the different pathways of the cells circulating in the water column should be considered at the time to assess primary productivity in areas exposed to changing meteorological conditions throughout the year, and hence with variable UMLs.
\end{abstract}

Key words: Dunaliella salina, Heterocapsa triquetra, Thalassiosira weissflogii, mixing, oxygen rates, photosynthetically active radiation, ultraviolet radiation.

\section{Dinámica de producción / consumo de oxígeno en Dunaliella salina, Thalassiosira weissflogii and Heterocapsa triquetra circulando dentro de una capa superficial de mezcla simulada*}

RESUMEN. Se determinó experimentalmente la dinámica de producción / consumo de oxígeno en tres especies fitoplanctónicas (20-25 $\mu \mathrm{m}$ de diámetro efectivo): Dunaliella salina (Chlorophyceae), Thalassiosira weissflogii (Bacillariophyceae) y Heterocapsa triquetra (Dinophyceae), cuando las células circularon dentro de una capa superficial de mezcla (CSM) simulada. Las muestras fueron expuestas a tres tratamientos de radiación recibiendo: a) toda la radiación solar (PAB, 280-700 nm), b) PAR+RUV-A (PA, 320-700 nm), y c) sólo PAR (P, 400-700 nm). Se simularon dos recorridos (como si las células circularan desde la superficie o desde la base de la CSM): 1) circulación hacia abajo (i.e., desde el 100\% al $9 \%$ de la irradiancia y nuevamente al 100\%), y 2) circulación hacia arriba (i.e., desde el 9\% al 100\% de la irradiancia y nuevamente al 9\%). No se encontraron diferencias significativas entre tratamientos de radiación $(\mathrm{p}<0,05)$ y la inhibición fotosintética se debió sólo a PAR. Se encontraron importantes diferencias inter-específicas en las tasas de oxígeno cuando las células circularon dentro de la CSM simulada, D. salina fue afectada tanto por altas como por bajas irradiancias, mientras que $T$. weissflogii solo fue inhibida por altas irradiancias. En cambio, H. triquetra mostró la menor variabilidad y se benefició por los regímenes fluctuantes de irradiancia. También se determinaron diferencias en la producción de

* Trabajo presentado en el XXV Congreso de Ciencias del Mar de Chile y XI Congreso Latinoamericano de Ciencias del Mar (COLACMAR), realizados en Viña del Mar, entre el 16 y 20 de mayo de 2005. 
$\mathrm{O}_{2}$ integrada en profundidad cuando las especies realizaron una rotación completa dentro de la CSM simulada, con los mayores valores en $H$. triquetra y los menores en $D$. salina. Estos resultados sugieren que los diferentes recorridos de las células circulando en la columna de agua deberían ser considerados al momento de determinar la productividad primaria en áreas expuestas a condiciones meteorológicas cambiantes durante el año, y consecuentemente, con CSMs variables.

Palabras clave: Dunaliella salina, Heterocapsa triquetra, Thalassiosira weissflogii, mezcla, tasa de oxígeno, radiación fotosintética activa, radiación ultravioleta.

Corresponding authør: Walter Helbling (whelbling@efpu.org.ar)

\section{INTRODUCTION}

Fluctuations of physical factors are widely known to affect significantly aquatic organisms (Steele, 1985); in particular, variations in the underwater radiation field have profound effects on phytoplankton. These fluctuations in irradiance occur by changes in the depth of the upper mixed layer (UML), a layer of homogeneous characteristics that is generally produced by wind stress and solar heating (Neale et al., 2003). Mixing causes phytoplankton to move in the water column and hence alter their exposure to solar radiation. This has important consequences on physiological processes, such as photosynthesis rates and respiration (Marra, 1978; Yoder \& Bishop, 1985; Kroon et al., 1992), growth (Ibelings et al., 1994; Litchman, 2000) and nutrient uptake (Litchman et al., 2004). Moreover, fluctuating light regimes may stimulate the growth of different species, hence potentially changing the phytoplankton taxonomic composition of the community (Litchman, 1998).

Studies have shown variable effects of mixing on phytoplankton photosynthetic rates. For example, Marra (1978) determined that vertical mixing significantly enhanced primary productivity, whereas Kroon et al. (1992) found that photosynthesis rates were depressed under fluctuating radiation regimes; on the other hand, Yoder \& Bishop (1985) did not find differences in photosynthetic rates when comparing them with those at fixed irradiances. The combined effects of mixing and solar ultraviolet radiation (UVR, 280-400 nm) are also known to affect phytoplankton primary productivity (Helbling et al., 1994; Neale et al., 1998; Kohler et al., 2001; Barbieri et al., 2002). Furthermore, mixing speed strongly affects photosynthetic rates (Helbling et al., 1994, 2003; Neale et al., 1998) and Helbling et al. (2003) demonstrated that fast mixing favored the utilization of UVR as source of energy for photosynthesis in tropical phytoplankton, whereas slow mixing caused a stronger UVR-induced photoinhibitory effect. On the other hand, Helbling et al. (1994) and Neale et al. (1998) working with Antarctic phytoplankton showed higher inhibition with rapid mixing, thus demonstrating that the interactive effects of UVR and mixing are strongly dependant on the specific sensitivity of phytoplankton assemblages as well as on the exposure response (i.e., irradiance / dose).

Although much progress have been done to understand phytoplankton responses when exposed to fluctuating radiation regimes, we are not aware of any study assessing primary productivity in mixed environments that has specifically considered the pathway that cells perform within the UML, i.e., if cells circulate from low towards high irradiances or vice versa. In this study, we simulated the rotation of phytoplankton cells (Dunaliella salina; Chlorophyceae, Thalassiosira weissflogii; Bacillariophyceae and Heterocapsa triquetra; Dinophyceae), within the UML under two extreme conditions (or pathways): in one of such pathways, cells that were at the bottom of the UML circulated upward to high irradiances (i.e., towards the surface) and back again ("upward" circulation). In the other type of circulation, cells that were at the surface moved downward to low irradiances (i.e., towards the bottom of the UML) and back again ("downward" circulation). As cells size plays an important role in the acclimation and responses to solar radiation (Helbling et al., 2001a) we are simplifying inter-specific comparisons by using organisms with a similar effective diameter (20-25 $\mu \mathrm{m})$.

\section{MATERIALS AND METHODS}

\section{Cultures}

Three marine phytoplankton species $(20-25 \mu \mathrm{m}$ in effective diameter) were used in the experiments: 
Dunaliella salina (Dunal) Teodoresco (Clorophyceae), Thalassiosira weissflogii (Grunow) G. Fryxell et Hasle (Bacillariophyceae) and Heterocapsa triquetra (Ehrenberg) Stein (Dinophyceae). The organisms used in these experiments were obtained from the Institut für Botanik und Pharmazeutische Biologie (Friedrich Alexander Universität, Germany) and from the Algae Culture Collection of Estación de Fotobiología Playa Unión. Cells were grown in seawater-enriched medium $\mathrm{f} / 2$ (Guillard \& Ryther, $1962)$ in a temperature controlled $\left(20^{\circ} \mathrm{C}\right)$ illuminated chamber (12:12, light: dark period) receiving PAR irradiance of $37 \mathrm{~W} \cdot \mathrm{m}^{-2}$, provided by 10 fluorescent Philips daylight lamps.

\section{Experimentation}

When cultures reached the exponential growth phase, they were transferred, during the light period, to an oxymeter (Real Time Computer Inc., model Oxym 5). The oxymeter has five $20 \mathrm{ml}$ quartz tubes inside of an acrylic UV transparent chamber with circulating water as temperature control (Fig. 1). Five oxygen microelectrodes (Yellow Spring Instruments Co., model 5331) were attached to the quartz tubes. Gentle mixing was done with a magnetic stirrer to maintain oxygen concentration homogeneous inside each quartz tube and to prevent the formation of bubbles. To test the effects of the different wavebands, samples were put in the quartz tubes under three treatments: a) PAB treatment (samples exposed to UVR+PAR; 280$700 \mathrm{~nm}$ ) uncovered tubes; b) PA treatment (samples exposed to UV-A+PAR; 320-700 nm) tubes covered with a cut-off filter (Montagefolie, Folex, Dreieich, Germany, 50\% transmission at $320 \mathrm{~nm}$ ) and, c) P treatment (samples exposed only to PAR; 400-700 $\mathrm{nm}$ ) tubes covered with Ultraphan -395 film (UV Opak, Digefra, Munich, Germany, 50\% transmission at $395 \mathrm{~nm}$ ) (the spectra of filters and materials are published in Figueroa et al. 1997). The oxymeter containing the samples was then exposed to natural radiation, and data from the five oxygen sensors, together with temperature and PAR irradiance were acquired every two seconds and recorded in a laptop computer.

Mixing was simulated based on real weather conditions of the Patagonia costal area, with a mean daily wind speed of $88 \mathrm{~km} \cdot \mathrm{h}^{-1}$ during spring and summer (Villafañe et al., 2004). We used different combinations of neutral density screens (Helbling et al., 1994; Barbieri et al., 2002) (Fig. 1) so that the simulated

Down circulation: 100 to 9 and back to $100 \%$ of total irradiance

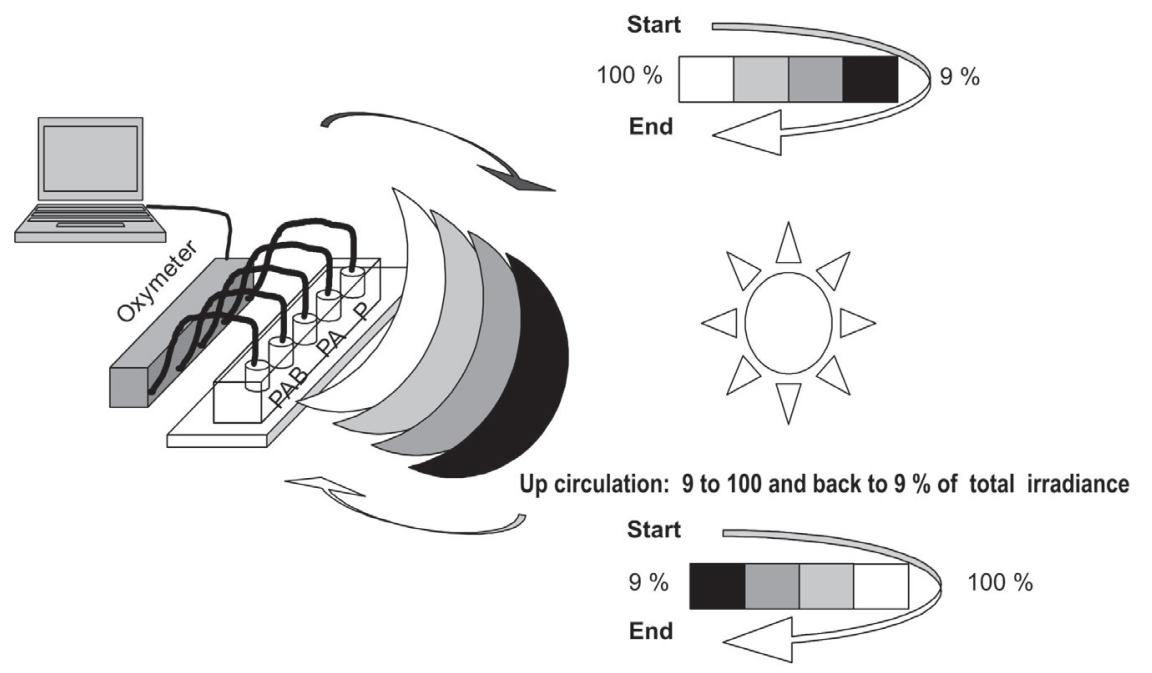

Figure 1. Schematic representation of the experimental set-up. Samples were put in the oxymeter under three radiation treatments (PAB, PA and P). Circulation of cells within the UML was simulated by adding / taking out neutral density screens that were placed in front of the oxymeter. A laptop computer recorded $\mathrm{O}_{2}$ evolution with a frequency of one datum every two seconds.

Figura 1. Representación esquemática del diseño experimental. Las muestras se colocaron en un oxímetro bajo tres tratamientos de radiación (PAB, PA y P). La circulación de las células en la CSM se simuló agregando / quitando mallas de densidad neutra que se colocaron en frente al oxímetro. Una computadora portátil registró la evolución de $\mathrm{O}_{2}$ con una frecuencia de un dato cada dos segundos. 
depth of the UML was $10 \mathrm{~m}\left(\mathrm{z}_{\mathrm{UML}}=10 \mathrm{~m}\right.$, Barbieri et al., 2002). Our imposed mixing conditions, together with the irradiance at which the cells were grown before used in experimentation $-37 \mathrm{~W} \cdot \mathrm{m}^{-2}$ - were chosen to establish the worst case scenario, as this irradiance value represents roughly the bottom of the simulated UML using an attenuation coefficient $\left(\mathrm{k}_{\mathrm{PAR}}\right)=0.3 \mathrm{~m}^{-1}$ (as previously determined for the study area) and the surface irradiance (Barbieri et $a l ., 2002)$. For each species, we performed two types of experiments (as if cells circulated in two different pathways) and each experiment was repeated twice. In one set of experiments ("downward" circulation) cells moved from $100 \%$ to $9 \%$ irradiance and back to $100 \%$. In the other set of experiments ("upward" circulation), cells moved from $9 \%$ to $100 \%$ irradiance and back to $9 \%$. We simulated four discrete steps of irradiance (i.e., $100 \%, 85 \%, 47 \%$ and $9 \%$ ) in the UML by adding / taking out neutral density screens every $20 \mathrm{~min}$, so that the total duration of each experiment (i.e., one rotation within the UML, $20 \mathrm{~min}$ at each irradiance step) was $160 \mathrm{~min}$. Although the simulated "upward" and "downward" circulations were done during different days (to keep the incubations centered on local noon) they were done under clear sky conditions (without cloud cover influence), with relatively similar PAR irradiance conditions during each step. The mean incident PAR irradiances registered were of 313,348 and $364 \mathrm{~W} \cdot \mathrm{m}^{-2}$ for experiments carried out with $D$. salina, T. weissflogii and $H$. triquetra, respectively. All experiments were carried out at Estación de Fotobiología Playa Unión (EFPU, $43.3^{\circ} \mathrm{S}, 65^{\circ} \mathrm{W}$ ) during the austral summer, during the period december 2003 - january 2004.

\section{Assessment of oxygen rates and integrated oxygen production}

Oxygen evolution (in $\mathrm{mg} \mathrm{O}_{2} \cdot \mathrm{L}^{-1}$ ) was plotted as a function of time. The data from each 20- min interval were adjusted to a lineal function (best fit) so that the slope represented $\mathrm{O}_{2}$ production rates (in $\mu \mathrm{g} \mathrm{O}_{2} \cdot \mathrm{L}^{-1} \cdot \mathrm{min}^{-1}$ ). Oxygen production rates were integrated over the turnover time (i.e., from 0 to $160 \mathrm{~min}$ ) as well as from 0 to $10 \mathrm{~m}$ (i.e., the depth of the simulated UML). Then, and to compare the integrated production among species, $\mathrm{O}_{2}$ production rates were normalized by cell concentration. The integrated $\mathrm{O}_{2}$ production over the simulated UML was thus calculated as:

$$
\text { Integrated } \mathrm{O}_{2} \text { production }=\frac{\left(\int_{0}^{10} \int_{0}^{160} O_{2} \text { rate } d t d z\right)}{\text { Cells concentration }}
$$

\section{Analyses and measurements}

Chlorophyll-a (chl-a) and UV-absorbing compounds: samples for chl-a were taken at the beginning and at the end of each experiment whereas those for spectral absorption characteristics were only taken at the beginning. An aliquot of $15-50 \mathrm{~mL}$ of sample was filtered onto Whatman GF/F filters $(25 \mathrm{~mm})$ and the pigments extracted in $7 \mathrm{~mL}$ of absolute methanol overnight at $4{ }^{\circ} \mathrm{C}$ (Holm-Hansen \& Riemann, 1978). After the extraction period, the sample was centrifuged and the extract scanned between 250 and $750 \mathrm{~nm}$ using a Hewlett Packard spectrophotometer (model HP-8453E). The peak height at $334 \mathrm{~nm}$ was used as an estimator of the concentration of UV-absorbing compounds (Dunlap et al., 1995). The same sample was used to determine chl-a concentration from readings taken before and after acidification using a Turner Designs fluorometer (model TD 700) (Holm-Hansen et al., 1965).

Enumeration of cells: phytoplankton samples were taken at the beginning and at the end of each experiment; the samples were fixed with buffered formalin (final concentration in the sample $0.4 \%$ ). Quantitative analyses of cells were done using a Sedwick-Rafter chamber following the technique described in Villafañe \& Reid (1995).

Radiation measurements: irradiance levels during experiments were monitored using a broad-band filter radiometer (ELDONET, Real Time Computer Inc.) which is permanently installed on the roof of the EFPU. This sensor collects data of incident solar radiation once per min for PAR $(400-700 \mathrm{~nm}), \mathrm{UV}-\mathrm{A}$ $(315-400 \mathrm{~nm})$ and UV-B $(280-315 \mathrm{~nm})$.

Statistics: in the three species studied, no significant differences $(p>0.05)$ were established between radiation treatments at any irradiance level (see below). Therefore, we combined and used the data from the five oxymeter channels (i.e., as quintuplicate samples) to calculate mean $\mathrm{O}_{2}$ rates and to perform all statistics. The Kruskal-Wallis non-parametric test (Zar, 1984) was used to establish differences between irradiance levels (confidence level $=0.05$ ) as well as in the integrated $\mathrm{O}_{2}$ production.

\section{RESULTS}

The absorption characteristics (i.e., optical density (O.D.) normalized by chl-a concentration) of $D$. $s a-$ lina, T. weissflogii and H. triquetra are shown in Fig. 2. The three species showed the chl-a peaks at 440 
and $665 \mathrm{~nm}$; carotenoids $\left(\lambda_{\max }=470 \mathrm{~nm}\right)$ were noticeable in D. salina and T. weissflogii whereas in $H$. triquetra only a small shoulder of these compounds was observed. On the other hand, this dinoflagellate had a clear peak of UV-absorbing compounds $\left(\lambda_{\text {max }}\right.$ $=334 \mathrm{~nm}$ ) whereas in $T$. weissflogii their amount were very small; they were virtually absent in $D$. salina. In all experiments, the concentration of cells was comparable and it varied between 1,800 and 2,200 cells $\cdot \mathrm{mL}^{-1}$.

In $D$. salina (Fig. 3) $\mathrm{O}_{2}$ evolution rates at the beginning of experiments were negative (i.e., $\mathrm{O}_{2}$ consumption) regardless if samples were exposed to a "downward" or an "upward" circulation. When the "upward" circulation was imposed to the cells, $\mathrm{O}_{2}$ rates increased significantly $(\mathrm{p}<0.001)$ as soon as the cells moved towards high irradiances, with positive $\mathrm{O}_{2}$ rates measured all the way up to the maximum experimental irradiance $\left(\right.$ i.e., $374 \mathrm{~W} \cdot \mathrm{m}^{-2}$ ) as well as during the way back to low irradiances $-32 \mathrm{~W} \cdot \mathrm{m}^{-2}$. There was a slight negative value of -2.5 $\mu \mathrm{g} \mathrm{O}_{2} \cdot \mathrm{L}^{-1} \cdot \mathrm{min}^{-1}$ when cells were exposed to irradiances of $172 \mathrm{~W} \cdot \mathrm{m}^{-2}$; this value, however, was not significantly different $(p>0.05)$ from that of 0.93 $\mu \mathrm{g} \mathrm{O}_{2} \cdot \mathrm{L}^{-1} \cdot \mathrm{min}^{-1}$ measured at the lowest irradiance at the end of the "upward" circulation. When cells circulated "downward" towards low irradiances, $\mathrm{O}_{2}$ consumption was measured in the first two steps of the simulated UML (i.e., at 343 and $201 \mathrm{~W} \cdot \mathrm{m}^{-2}$ ) as well as at the lowest experimental irradiance (i.e., 20 $\mathrm{W} \cdot \mathrm{m}^{-2}$ ); during the rest of the experiment however, there was a positive $\mathrm{O}_{2}$ balance. The maximum $\mathrm{O}_{2}$ rate was determined during the "upward" circulation $-14.7 \mu \mathrm{g} \mathrm{O}_{2} \cdot \mathrm{L}^{-1} \cdot \mathrm{min}^{-1}$ at $319 \mathrm{~W} \cdot \mathrm{m}^{-2}$. In the "downward" circulation though, maximum $\mathrm{O}_{2}$ production values were significantly lower $(\mathrm{p}<0.05)(9.3 \mu \mathrm{g}$ $\mathrm{O}_{2} \cdot \mathrm{L}^{-1} \cdot \mathrm{min}^{-1}$ at $233 \mathrm{~W} \cdot \mathrm{m}^{-2}$ ), than that determined during the "upward" circulation.

In $T$. weissflogii (Fig. 4) $\mathrm{O}_{2}$ rates had a relatively high value of $15.95 \mu \mathrm{g} \mathrm{O}_{2} \cdot \mathrm{L}^{-1} \cdot \mathrm{min}^{-1}$ at the beginning of the "upward" circulation (i.e., $23 \mathrm{~W} \cdot \mathrm{m}^{-2}$ ) but they decreased with increasing irradiances. At the maximum irradiance (i.e., $357 \mathrm{~W} \cdot \mathrm{m}^{-2}$ ) $\mathrm{O}_{2}$ rates at the end of the first half of the experiment $(6.68 \mu \mathrm{g}$ $\left.\mathrm{O}_{2} \cdot \mathrm{L}^{-1} \cdot \mathrm{min}^{-1}\right)$ were not significantly different $(\mathrm{p}>$ 0.05 ) from that at the beginning of the second part $\left(0.55 \mu \mathrm{g} \mathrm{O}_{2} \cdot \mathrm{L}^{-1} \cdot \mathrm{min}^{-1}\right)$. When samples returned to low irradiances, however, $\mathrm{O}_{2}$ rates were negative $\left(\sim-8.40--7.03 \mu \mathrm{g} \mathrm{O}_{2} \cdot \mathrm{L}^{-1} \cdot \mathrm{min}^{-1}\right)$. Samples of $T$. weissflogii during the "downward" circulation initially displayed very high $\mathrm{O}_{2}$ consumption rates of $40.57 \mu \mathrm{g} \mathrm{O}_{2} \cdot \mathrm{L}^{-1} \cdot \mathrm{min}^{-1}$ at $317 \mathrm{~W} \cdot \mathrm{m}^{-2}$. As soon as irradiance decreased, we measured $\mathrm{O}_{2}$ production, as high as $20.23 \mu \mathrm{g} \mathrm{O}_{2} \cdot \mathrm{L}^{-1} \cdot \mathrm{min}^{-1}$ at $253 \mathrm{~W} \cdot \mathrm{m}^{-2}$. Relatively high $\mathrm{O}_{2}$ production rates (i.e., 16-19 $\mu \mathrm{g} \mathrm{O}_{2} \cdot \mathrm{L}^{-1} \cdot \mathrm{min}^{-1}$ ) were determined at intermediate irradiances; however, slight $\mathrm{O}_{2}$ consumption was determined at the lowest irradiance (i.e., $31 \mathrm{~W} \cdot \mathrm{m}^{-2}$ ) but $\mathrm{O}_{2}$ rates increased again towards the end of this experiment.

Finally, the samples of $H$. triquetra (Fig. 5) moving from low towards high irradiances had positive

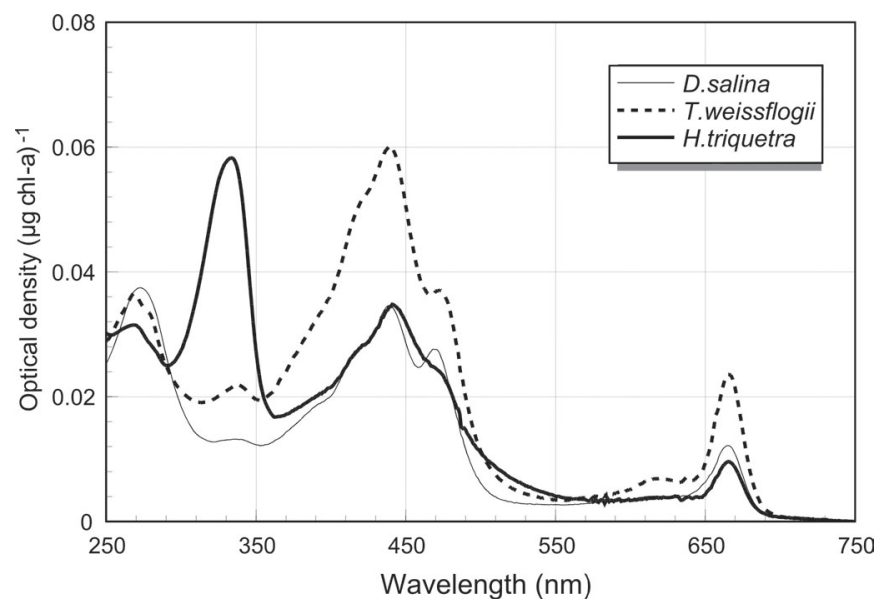

Figure 2. Initial absorption characteristics (Optical density per unit chl-a) as a function of wavelength for Dunaliella salina (thin line), Thalassiosira weissflogii (broken line) and Heterocapsa triquetra (thick line).

Figura 2. Características de absorción iniciales (Densidad óptica por clor-a) en función de la longitud de onda de $D u$ naliella salina (línea fina), Thalassiosira weissflogii (línea entrecortada) y Heterocapsa triquetra (línea gruesa). 


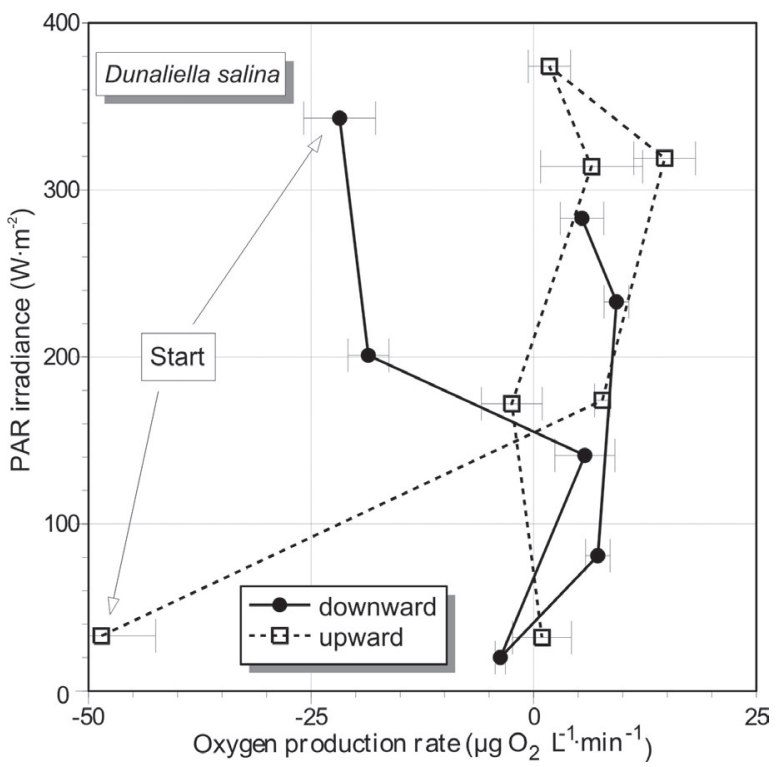

Figure 3. Mean $\mathrm{O}_{2}$ production rates $\left(\mu \mathrm{g} \mathrm{O}_{2} \mathrm{~L}^{-1} \cdot \mathrm{min}^{-1}\right)$ for Dunaliella salina as a function of PAR irradiance during the "upward" (open squares) and "downward" (black circles) circulations. The horizontal lines indicate the standard deviation, and the arrows represent the starting point of each circulation.

Figura 3. Tasa media de producción de $\mathrm{O}_{2}\left(\mu \mathrm{g} \mathrm{O}_{2} \mathrm{~L}^{-1} \cdot \mathrm{min}^{-1}\right)$ para Dunaliella salina en función de la irradiancia PAR durante el movimiento "hacia arriba" (cuadrados blancos) y "hacia abajo" (círculos negros). Las líneas horizontales indican la desviación estándar y las flechas el comienzo de cada circulación.

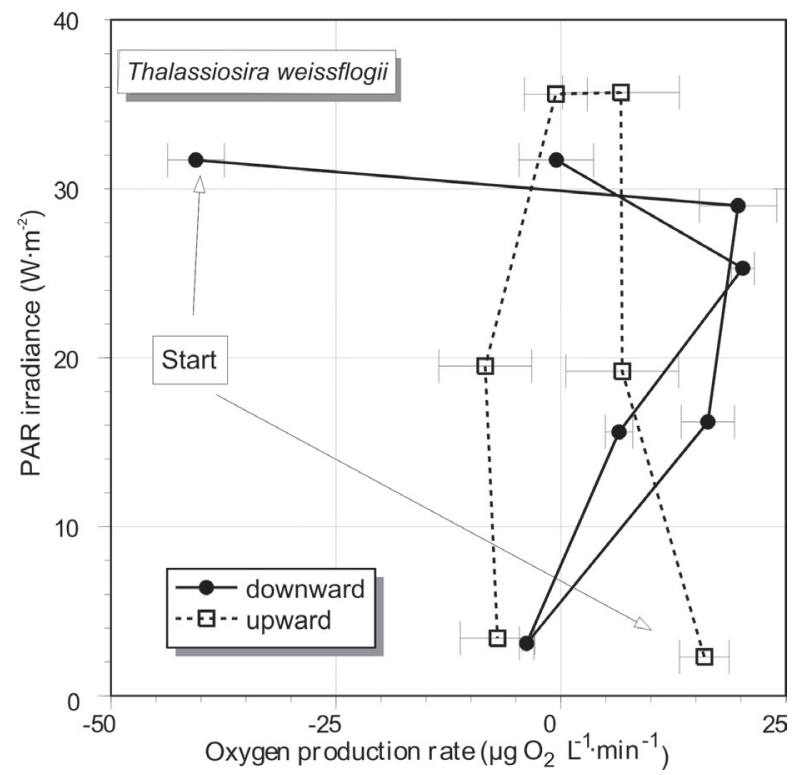

Figure 4. Mean $\mathrm{O}_{2}$ production rates $\left(\mu \mathrm{g} \mathrm{O} \mathrm{L}^{-1} \cdot \mathrm{min}^{-1}\right)$ for Thalassiosira weissflogii as a function of PAR irradiance during the "upward" (open squares) and "downward" (black circles) circulations. The horizontal lines indicate the standard deviation, and the arrows represent the starting point of each circulation. One datum is missing during the "upward" circulation.

Figura 4. Tasa media de producción de $\mathrm{O}_{2}\left(\mu \mathrm{g} \mathrm{O}_{2} \mathrm{~L}^{-1} \cdot \mathrm{min}^{-1}\right)$ para Thalassiosira weissflogii en función de la irradiancia PAR durante el movimiento "hacia arriba" (cuadrados blancos) y "hacia abajo" (círculos negros). Las líneas horizontales indican la desviación estándar y las flechas el comienzo de cada circulación. Se perdió un dato durante la circulación "hacia arriba". 
$\mathrm{O}_{2}$ rates throughout almost all the experiment, with maximum production values of $12.70 \mu \mathrm{g} \mathrm{O} \cdot \mathrm{L}^{-1} \cdot \mathrm{min}^{-1}$ at $160 \mathrm{~W} \cdot \mathrm{m}^{-2}$. A minimum value of $-10.20 \mu \mathrm{g} \mathrm{O} \mathrm{O}_{2} \cdot \mathrm{L}^{-}$ ${ }^{1} \cdot \mathrm{min}^{-1}$ was found at the end of the "upward" circulation (i.e., at $30 \mathrm{~W} \cdot \mathrm{m}^{-2}$ ). During the "downward" circulation, samples of $H$. triquetra had positive $\mathrm{O}_{2}$ rates values during the first half of the experiment (i.e., when circulating towards low irradiances). However, $\mathrm{O}_{2}$ was slightly consumed at intermediate irradiances (i.e., $189 \mathrm{~W} \cdot \mathrm{m}^{-2}$ ), recovering to $15.36 \mu \mathrm{g}$ $\mathrm{O}_{2} \cdot \mathrm{L}^{-1} \cdot \mathrm{min}^{-1}$ at $350 \mathrm{~W} \cdot \mathrm{m}^{-2}$

To compare the photosynthetic performance $\left(\mathrm{O}_{2}\right.$ consumption / production) of the species studied, we calculated the depth integrated $\mathrm{O}_{2}$ production during a complete rotation within the simulated UML (Fig. 6). All species produced $\mathrm{O}_{2}$ during the "downward" circulation. During this circulation, no significant differences in $\mathrm{O}_{2}$ production rates $(\mathrm{p}>0.05)$ were found between $T$. weissflogii and $H$. triquetra but $\mathrm{O}_{2}$ production in D. salina was significantly lower $(\mathrm{p}<0.05)$. When mixing started from low towards high irradiances, the three species displayed significant differ- ences in the depth integrated $\mathrm{O}_{2}$ production $(\mathrm{p}<0.05)$. $H$. triquetra had the highest integrated production $\left(2.68 \mu \mathrm{g} \mathrm{O}_{2} \cdot \mathrm{m}^{-2} \cdot\right.$ cell $\left.^{-1}\right)$ whereas $D$. salina the lowest $\mathrm{O}_{2}$ consumption $\left(-0.64 \mu \mathrm{g} \mathrm{O}_{2} \cdot \mathrm{m}^{-2} \cdot\right.$ cell $\left.^{-1}\right)$; T. weissflogii produced $\mathrm{O}_{2}$ at a rate of $0.29 \mu \mathrm{g} \mathrm{O}_{2} \cdot \mathrm{m}^{-2} \cdot$ cell $^{-1}$. Finally, we determined significant inter-specific differences $(\mathrm{p}<0.05)$ in the integrated $\mathrm{O}_{2}$ production: $D$. salina and $T$. weissflogii had higher integrated $\mathrm{O}_{2}$ production in the "downward" as compared to the "upward" circulation; in H. triquetra however, the integrated $\mathrm{O}_{2}$ production during the "downward" was less than half of that in the "upward" circulation.

\section{DISCUSSION}

\section{Lack of UVR-induced photoinhibition}

Photosynthetic rates are clearly associated to the radiation quality under which the cells are exposed, with PAR being mostly responsible for photosynthesis, whereas UVR is generally considered a stress factor for this process (see review by Villafañe et al., 2003

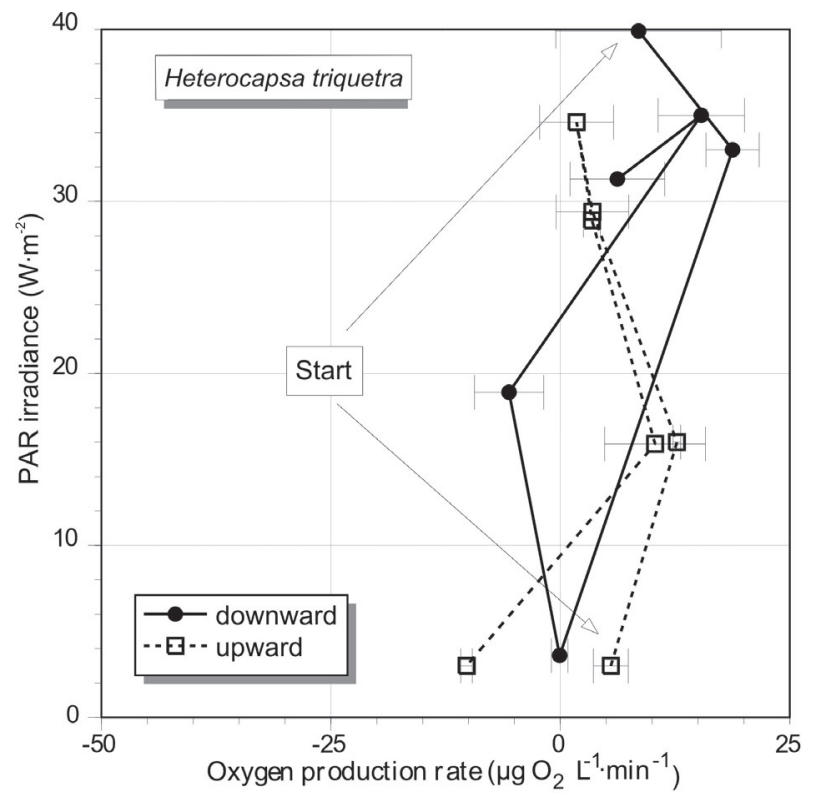

Figure 5. Mean $\mathrm{O}_{2}$ production rates $\left(\mu \mathrm{g} \mathrm{O}_{2} \mathrm{~L}^{-1} \cdot \mathrm{min}^{-1}\right)$ for Heterocapsa triquetra as a function of PAR irradiance during the "upward" (open squares) and "downward" (black circles) circulations. The horizontal lines indicate the standard deviation, and the arrows represent the starting point of each circulation. One datum is missing during the "downward" circulation.

Figura 5. Tasa media de producción de $\mathrm{O}_{2}\left(\mu \mathrm{g} \mathrm{O}_{2} \mathrm{~L}^{-1} \cdot \mathrm{min}^{-1}\right)$ para Heterocapsa triquetra en función de la irradiancia PAR durante el movimiento "hacia arriba" (cuadrados blancos) y "hacia abajo" (círculos negros). Las líneas horizontales indican la desviación estándar y las flechas el comienzo de cada circulación. Se perdió un dato durante la circulación "hacia abajo". 


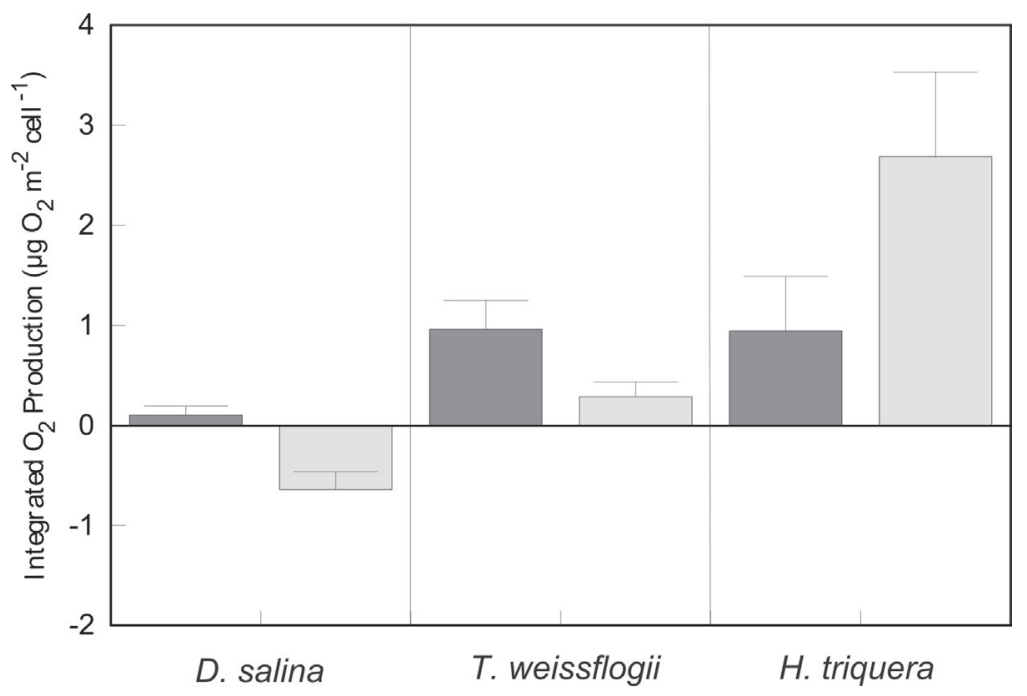

Figure 6. Integrated $\mathrm{O}_{2}$ production of $D$. salina, . weissflogii and $H$. triquetra during the "upward" (light bars) and "downward" (dark bars) circulations within a simulated UML $\left(Z_{U M L}=10 \mathrm{~m}\right)$. The lines on top of the bars represent the standard deviation. Full explanation in the text.

Figura 6. Producción integrada de $\mathrm{O}_{2}$ para $\mathrm{D}$. salina, T. weissflogii y $\mathrm{H}$. triquetra durante la circulación "hacia arriba" (barras claras) y "hacia abajo" (barras oscuras) dentro de una CSM simulada $\left(\mathrm{Z}_{\mathrm{CSM}}=10 \mathrm{~m}\right)$. Las líneas sobre las barras representan la desviación estándar. La explicación completa se encuentra en el texto.

and references therein). However, a wide range of responses to UVR is also reported: while some species are very resistant, e.g., from tropical environments (Helbling et al., 1992, 2001b) some others, e.g., from polar areas, are especially sensitive even under low UVR levels (Helbling et al., 1992, 1996). Other studies have also reported the utilization of UVR (mainly UV-A) when PAR levels are relatively low (Barbieri et al., 2002) or when phytoplankton cells mix fast within the UML (Helbling et al., 2003). In our study though, we did not find significant effects of solar UVR when the species were exposed to a variable mixing regime. This could be related to the fact that when cells changed their irradiance exposure, from the relatively low irradiances during the culturing condition at $37 \mathrm{~W} \cdot \mathrm{m}^{-2}$, to natural solar radiation, they were inhibited by PAR and thus, the contribution of UVR-inhibition was not significant. As previously mentioned, the irradiance conditions at which the cultures were maintained was similar to those received by the cells at the bottom of the UML. The relatively high PAR-induced photoinhibition as found in this study (Figs. 3-5) is also in agreement with other studies carried out in Patagonia (Villafañe et al., 2004) with phytoplankton exposed to similar radiation levels as that used in our experiments. In these studies, the authors reported that the UVR contribution to photoinhibition was relatively high only in winter, when PAR levels were low (Villafañe et al., 2004). Thus, the relatively high PAR-induced photoinhibition as compared to that of UVR seems to be a rather general feature for phytoplankton exposed to natural radiation levels as those received in the Patagonia area, with PAR / UVR ratios varying between 6.9-8.0 in summer and winter, respectively.

\section{Mixing effects on $\mathrm{O}_{2}$ rates: Inter-specific differences in $\mathrm{O}_{2}$ production}

Even under similar experimental conditions, there was an important degree of variability in the responses of the three phytoplankton species circulating within our simulated UMLs. This inter-specific variability is thought to occur by one or several processes (Litchman, 2000 and references therein), including differences in sensitivity among taxa (Richardson et al., 1983), variations in respiration rates which are dependant on irradiance (Falkowski et al., 1994), or variations in allocation of resources to protect the cells (Raven, 1994). For example, $\mathrm{O}_{2}$ rates in $D$. salina were strongly inhibited by both high and low irradiances at the beginning of circulation (Fig. 3) but after that, $\mathrm{O}_{2}$ rates increased again, although without reaching very high production. On the other hand, $\mathrm{O}_{2}$ rates of $T$. weissflogii (Fig. 4) were inhibited only by high irradiances in the "downward" circulation, whereas those in $H$. triquetra (Fig. 5) were rather 
similar throughout the irradiances changes simulated in our experiments.

The significant inhibition of $\mathrm{O}_{2}$ rates observed in D. salina (Fig. 3) and T. weissflogii (Fig. 4) during the "downward" circulation was rather expected, as cells were transferred from relatively low (i.e., $37 \mathrm{~W} \cdot \mathrm{m}^{-2}$, culture conditions) to high PAR irradiances $\left(>300 \mathrm{~W} \cdot \mathrm{m}^{-2}\right.$, experimental conditions). Even though this change in irradiances is large, we observed similar changes in the study area which were produced by intense mixing due to wind stress (Villafañe et al., 2004) and by variable cloud cover that result in changes in irradiances of one order of magnitude occurring within minutes (Helbling et al., 2005). These changing conditions obviously imply an energy cost for the cells to acclimate their photosynthetic apparatus to the variable radiation conditions (Kiefer, 1973) and in the case of our experiments this was translated in a reduction of $\mathrm{O}_{2}$ rates. However, our data do suggest dynamic rather than chronic photosynthetic inhibition in the three species studied. The mechanism of chronic inhibition is the light-dependent photodegradation of the D1 protein in photosystem II (PS II) which leads to a decrease in the photosynthetic electron transport (Osmond, 1994) and so, the photosynthetic apparatus is protected from excessive radiation energy. In contrast, dynamic photoinhibition is based on the xanthophyll cycle identified in higher plants and in many macroalgae (Häder \& Figueroa, 1997) so that when cells are exposed to excessive solar radiation, the quantum yield of PS II decreases and the excitation energy is dissipated thermally. In D. salina, photosynthetic inhibition during the "downward" circulation lasted longer (i.e., two steps in the rotation, Fig. 3) than in the other two species, suggesting that although irradiance decreased to $\sim 60 \%$ of the initial value, PAR still inhibited photosynthesis. On the other hand, the better performance of T. weissflogii compared to that of $D$. salina might be related to its absorption characteristics (Fig. 2) and to its siliceous structure that might prevent solar radiation to reach vital targets within the cell (e.g., photosystems, DNA, etc.) by acting as a passive shield. In fact, this species recovered very fast from the change of irradiance from laboratory to experimental conditions under solar radiation. For example, during the "downward" circulation the small change in irradiance from 320 to $290 \mathrm{~W} \cdot \mathrm{m}^{-2}$ that occurred over a $20 \mathrm{~min}$ interval, was enough to acclimate and to significantly increase $\mathrm{O}_{2}$ rates from $\sim-40 \mu \mathrm{g} \mathrm{O}_{2} \cdot \mathrm{L}^{-1} \cdot \mathrm{min}^{-1}$ to a maximum of ca. $20 \mu \mathrm{g} \mathrm{O}{ }_{2} \cdot \mathrm{L}^{-1} \cdot \mathrm{min}^{-1}$.
The responses to mixing of $H$. triquetra (Fig. 5) were rather different as compared to that in the other two species, as it did not show high variability in $\mathrm{O}_{2}$ rates in both "upward" and "downward" circulations. One might think that this response is related to the different absorption characteristics of this species (Fig. 2) as compared to that of D. salina and $T$. weissflogii that did not have significant amounts of UV-absorbing compounds, as it is normally the case in most Chlorophyceae and many diatom species (Banaszak, 2003). On the other hand, although $H$. triquetra had high concentrations of UV-absorbing compounds, as seen in many dinoflagellate species (Banaszak, 2003) and that would protect them from UVR stress, there were no significant differences between samples exposed and non-exposed to UVR; in fact, PAR contributed for most of photoinhibition. Thus, it is apparent that these UV-absorbing compounds are not responsible for the relatively low inhibition, unless these compounds are involved in other processes than just preventing UVR to reach vital parts of the cell. In fact, several additional functions of these compounds have been suggested (see review by Bandaranayake, 1998) and at least one of them, mycosporine-glycine, has been found to have antioxidant activity with mild effects as scavenger for free radicals (Dunlap \& Yamamoto, 1995). Even though here we are not testing the role of these compounds, we can not rule out the possibility that they might be involved in other metabolic processes within the cell, thus resulting in an overall better and faster acclimation of $H$. triquetra to the changing irradiance conditions. Overall, it is seen that the differential species' performance is translated in important inter-specific differences in the integrated $\mathrm{O}_{2}$ production (Fig. 6): the highest production rates were determined in $H$. triquetra, whereas the lowest values (i.e., $\mathrm{O}_{2}$ consumption) were registered in $D$. salina. Additionally, relatively large differences were determined according to the pathway followed by each species: D. salina and T. weissflogii had higher $\mathrm{O}_{2}$ rates when circulation started at high irradiances, whereas the opposite occurred in H. triquetra (Fig. $6)$.

\section{Ecological implications}

Our results may have important ecological implications for natural assemblages of phytoplankton in areas exposed to a variable atmospheric and climatologically conditions such as those of the Patagonian coast (Villafañe et al., 2004). In this study, we compared the responses of three microplanktonic 
species that are typical of summer (D. salina), spring (T. weissflogii) and harmful algae bloom conditions (H. triquetra). We showed that they displayed a differential behavior in relation to mixing, being $H$. triquetra the species that obtained more benefits from fluctuating irradiance conditions, whereas $D$. salina would be more affected in such changing environment (Fig. 6). Changes in irradiance as those used in our experimental set-up would be found, for example, in our study site in the Patagonian region, where daily doses of solar radiation vary from 1 to $14 \mathrm{MJ} \cdot \mathrm{m}^{-2}$ for PAR, and from 150 to 2000 , and 5 to $42 \mathrm{~kJ} \cdot \mathrm{m}^{-2}$, for UV-A and UV-B, respectively (Villafañe et al., 2004). In addition, the study area is characterized by strong winds with a mean daily value of $88 \mathrm{~km} \cdot \mathrm{h}^{-1}$ and maximum wind speed frequency in the range of 12-16 $\mathrm{Km} \cdot \mathrm{h}^{-1}$ during spring and summer; on the other hand, relatively calm weather is characteristic from winter time (Villafañe et al., 2004). Under these conditions, variable portions of the euphotic zone $-\mathrm{E}_{\mathrm{u}}$ (that in general extend down to $c a 15 \mathrm{~m}$ ) are mixed, and the upper mixed layer (UML) can encompass from $c a$ $50 \%$ to almost the whole $\mathrm{E}_{\mathrm{u}}$ (Barbieri et al., 2002). It is important to point out that in the experiments we did not simulate the differential attenuation of solar irradiance within the UML so that our ratios of energy (short versus long wavelengths) were maximal, and thus they represented the worst-case scenario. However, as mentioned above, we did not find any significant differences between radiation treatments, even with these high energies ratios. Whether phytoplankton acclimate in situ to those variable radiation regimes will depend on several factors, not only on the fluctuating irradiance levels received by cells, but also on other variables such as nutrient status, cell size and factors of intrinsic origin (i.e., specific sensitivity). In Patagonia, it has been reported that phytoplankton blooms (dominated by microplankton diatoms) occur during winter (Villafañe et al., 2004). However, and based on our results, if the responses of $H$. triquetra are indeed representative for the Dynophyceae group, their productivity would be favored under windy conditions. In fact, studies carried out by in Patagonia by Gayoso (2001) and Villafañe et al. (2004) have reported relatively high concentrations of dinoflagellates during the windy season (i.e., spring-summer) including toxic species such as Alexandrium tamarense. However, during this season phytoplankton biomass is relatively low (Villafañe et al., 2004) as availability of nutrients appear to be the most important variable limiting growth (Helbling et al., 2005).
We conclude from our results that at the time to assess phytoplankton acclimation to solar radiation, not only the changes in irradiance are important but also if they occur towards high or low levels. Under mixing conditions in the water column, in which various species co-exist, the inter-specific responses would lead to a dominance of the fittest in terms of adaptation to changes in irradiance that, in our case, it would mean that mixing would favor the development and growth of dinoflagellates.

\section{ACKNOWLEDGMENTS}

This work was supported by the Agencia Nacional de Promoción Científica y Tecnológica (PICT2000 $\mathrm{N}^{\circ}$ 07-08184 and PICT $2003 \mathrm{~N}^{\circ} 01-13388$ ) and Fundación Playa Unión. We thank Dr. D.P. Häder who kindly provided some cultures used in the experiments and J.I. Albarracín that helped in cultures' maintenance; C. Barrio helped with experimental set-up. We are grateful with the comments and suggestions of one reviewer that contributed to improve this manuscript. This is contribution $\mathrm{N}^{0} 90$ of the Estación de Fotobiología Playa Unión.

\section{REFERENCES}

Banaszak, A.T. 2003. Photoprotective physiological and biochemical responses of aquatic organisms to UVR. In: E.W. Helbling \& H.E. Zagarese (eds.). UV effects in aquatic organisms and ecosystems. The Royal Society of Chemistry, Cambridge, pp. 329-356.

Bandaranayake, W.M. 1998. Mycosporines: are they nature's sunscreens? Nat. Prod. Rep., 15: 159-172.

Barbieri, E.S., V.E. Villafañe \& E.W. Helbling. 2002. Experimental assessment of UV effects on temperate marine phytoplankton when exposed to variable radiation regimes. Limnol. Oceanogr., 47: 1648-1655.

Dunlap, W.C. \& Y. Yamamoto. 1995. Small molecular antioxidants in marine organisms: antioxidant activity of mycosporine-glycine. Comp. Biochem. Physiol., 112(B): 105-114.

Dunlap, W.C., G.A. Rae, E.W. Helbling, V.E. Villafañe \& O. Holm-Hansen. 1995. UV-absorbing compounds in natural assemblages of Antarctic phytoplankton. Antarct. J. US., 30: 323-326. 
Falkowski, P.G., R. Greene \& Z. Kolber. 1994. Light utilization and photoinhibition of photosynthesis in marine phytoplankton. In: N. Baker \& J. Bowyer (eds.). Photoinhibition of photosynthesis: from molecular mechanisms to the field. Bios Scientific, Oxford, pp. 407-432.

Figueroa, F.L., S. Salles, J. Aguilera, C. Jiménez, J. Mercado, B. Viñegla, A. Flores-Moya \& M. Altamirano. 1997. Effects of solar radiation on photoinhibition and pigmentation in the red alga Porphyra leucosticta. Mar. Ecol. Progr. Ser., 151: 81-90.

Gayoso, A.M. 2001. Observations on Alexandrium tamarense (Lebour) Balech and other dinoflagellate populations in golfo Nuevo, Patagonia (Argentina). J. Plankton Res., 23: 463-468.

Guillard, R.R.L. \& J.H. Rhyter. 1962. Studies of marine planktonic diatoms. I. Cyclotella nana Hustedt, and Detonula confervacea (Cleve) Gran. Can. J. Microbiol., 8: 229-239.

Häder, P.D. \& F.L. Figueroa. 1997. Photoecophysiology of marine macroalgae. Photochem. Photobiol., 66: $1-14$

Helbling, E.W., H.C. Eilertsen, V.E. Villafañe \& O. Holm-Hansen. 1996. Effects of ultraviolet radiation on post-bloom phytoplankton populations in Kvalsund, North Norway. J. Photochem. Photobiol., B-Biol., 33: 255-259.

Helbling, E.W., K. Gao, R.J. Gonçalves, H. Wu \& V.E. Villafañe. 2003. Utilization of solar UV radiation by coastal phytoplankton assemblages off SE China when exposed to fast mixing. Mar. Ecol. Progr. Ser., 259: 59-66.

Helbling, E.W., V.E. Villafañe \& E.S. Barbieri. 2001a. Sensitivity of winter phytoplankton communities from Andean lakes to artificial ultraviolet-B radiation. Rev. Chil. Hist. Nat., 74: 273-282.

Helbling, E.W., V.E. Villafañe \& O. Holm-Hansen. 1994. Effects of ultraviolet radiation on Antarctic marine phytoplankton photosynthesis with particular attention to the influence of mixing. In: C.S. Weiler \& P.A. Penhale (eds.). Ultraviolet radiation in Antarctica: measurements and biological effects. American Geophysical Union, Washington, DC, pp. 207-227.

Helbling, E.W., V.E. Villafañe, A.G.J. Buma, M.Andrade \& F. Zaratti. 2001b. DNA damage and photosynthetic inhibition induced by solar UVR in tropical phytoplankton (Lake Titicaca, Bolivia). Eur. J. Phycol., 36: 157-166.
Helbling, E.W., V.E. Villafañe, M. Ferrario \& O. Holm-Hansen. 1992. Impact of natural ultraviolet radiation on rates of photosynthesis and on specific marine phytoplankton species. Mar. Ecol. Progr. Ser., 80: 89-100.

Helbling, E.W., E.S. Barbieri, M.A. Marcoval, R.J. Gonçalves \& V.E. Villafañe. 2005. Impact of solar ultraviolet radiation on marine phytoplankton of Patagonia, Argentina. Photochem. Photobiol., 81: 807-818.

Holm-Hansen, O. \& B. Riemann. 1978. Chlorophyll a determination: improvements in methodology. Oikos, 30: 438-447.

Holm-Hansen, O., C.J. Lorenzen, R.W. Holmes \& J.D.H. Strickland. 1965. Fluorometric determination of chlorophyll. J. Cons. Explor. Mer., 30: 3-15.

Ibelings, B.W., B.M.A. Kroon \& L.R. Mur. 1994. Acclimation of photosystem II in a cyanobacterium and a eukaryotic green alga to high and fluctuating photosynthetic photon flux densities, simulating light regimes induced by mixing in lakes. New Phytol., 128: 407-424.

Kiefer, D.A. 1973. Chlorophyll a fluorescence in marine centric diatoms: responses of chloroplasts to light and nutrient stress. Mar. Biol., 23: 39-46.

Kohler, J., M. Schmitt, H. Krumbeck, M. Kapfer, E. Litchman \& P.J. Neale. 2001. Effects of UV on carbon assimilation of phytoplankton in a mixed water column. Aquat. Sci., 63: 294-309.

Kroon, B.M.A., M. Latasa, B.W. Ibelings \& L.R. Mur. 1992. The effect of dynamic light regimes on Chlorella. I. Pigments and cross sections. Hydrobiologia, 238: 71-78.

Litchman, E., C.A. Klausmeier \& P. Bossard. 2004. Phytoplankton nutrient competition under dynamic light regimes. Limnol. Oceanogr., 49: 1457-1462.

Litchman, E. 2000. Growth rates of phytoplankton under fluctuating light. Freshwat. Biol., 44: 223-235.

Litchman, E. 1998. Population and community responses of phytoplankton to fluctuating light. Oecologia, 117: 247-257.

Marra, J. 1978. Phytoplankton photosynthetic response to vertical movement in a mixed layer. Mar. Biol., 46: 203-208.

Neale, P.J., E.W. Helbling \& H.E. Zagarese. 2003. Modulation of UVR exposure and effects by verti- 
cal mixing and advection. In: E.W. Helbling \& H.E. Zagarese (eds.). UV effects in aquatic organisms and ecosystems. The Royal Society of Chemistry, Cambridge, pp. 107-134.

Neale, P.J., R.F. Davis \& J.J. Cullen. 1998. Interactive effects of ozone depletion and vertical mixing on photosynthesis of Antarctic phytoplankton. Nature, 392: 585-589.

Osmond, C.B. 1994. What is photoinhibition? Some insights from comparison of shade and sun plants. In: N. Baker \& J. Bowyer (eds.). Photoinhibition of photosynthesis: from molecular mechanisms to the field. Bios Scientific, Oxford, pp. 1-24.

Raven, J.A. 1994. The cost of photoinhibition to plant communities. In: N. Baker \& J. Bowyer (eds.). Photoinhibition of photosynthesis: from molecular mechanisms to the field. Bios Scientific, Oxford, pp. 449-464.

Richardson, K., J. Beardall \& J.A. Raven. 1983. Adaptation of unicellular algae to irradiance: an analysis of strategies. New Phytol., 93: 157-191.

Steele, J.H. 1985. A comparison of terrestrial and marine ecological systems. Nature, 313: 355-358.

Recibido: 16 mayo 2006; Aceptado 20 octubre 2006
Villafañe, V.E. \& F.M.H. Reid. 1995. Métodos de microscopía para la cuantificación del fitoplancton. In: K. Alveal, M.E. Ferrario, E.C. Oliveira \& E. Sar (eds.). Manual de métodos ficológicos. Universidad de Concepción, Concepción, pp. 169-185.

Villafañe, V.E., E.S. Barbieri \& E.W. Helbling. 2004. Annual patterns of ultraviolet radiation effects on temperate marine phytoplankton off Patagonia, Argentina. J. Plankton Res., 26: 167-174.

Villafañe, V.E., K. Sundbäck, F.L. Figueroa \& E.W. Helbling. 2003. Photosynthesis in the aquatic environment as affected by UVR. In: E.W. Helbling \& H.E. Zagarese (eds.). UV effects in aquatic organisms and ecosystems. The Royal Society of Chemistry, Cambridge, pp. 357-397.

Yoder, J.A. \& S.S. Bishop. 1985. Effects of mixinginduced irradiance fluctuations on photosynthesis of natural assemblages of coastal phytoplankton. Mar. Biol., 90: 87-93.

Zar, J.H. 1984. Biostatistical analysis. Prentice Hall, New Jersey, USA, 718 pp. 